\title{
Lignin phenols content and distribution in gran-size fractions of soils
}

Kovalev I.V., Kovaleva N.O.

Lomonosov Moscow State University, Soil Science Faculty, Russia, kovalevmsu@mail.ru

Keywords: lignin phenols, gran-size fractions, organo-mineral interactions

doi: 10.36291/HIT.2019.kovalev.034

The complex aromatic structure and hydrophobic properties of lignin, as well as its high biochemical stability determine the unique role of this biopolymer in the processes of humification, organomineral interactions and structure formation. Typical structural fragments of lignin in soils are also recognizable for a long time, because fragments of partially decomposed lignin unavailable for microorganisms are stabilized on the external surfaces of metal oxides or clay minerals.

Quantile distribution of lignin (lignin oxidation products (VSC), mg/g Corg.), the degree of oxidation $(\mathrm{ac} / \mathrm{al})_{\mathrm{v}}$, the degree of lignin transformation with respect to the original plant tissue $(T, \%)$ in gran-size fractions of soils of the North Caucasus and gray soils of the Moscow region showed that with a decrease of the fraction size $(<2 \mu \mathrm{m}, 2-20 \mu \mathrm{m})$, the amount of lignin in them is significantly reduced - 10 times compared with large fractions $(20-250 \mu \mathrm{m},>250 \mu \mathrm{m})$. Most of the oxidation products of lignin phenols (up to $50 \%$ ) are associated with the coarse sand fraction $(>250 \mu \mathrm{m})$. However, maximum oxidation level (ac/al)v and the degree of biopolymer transformation $(\mathrm{T}, \%)$ and low values of S/V-relations is observed in the most shallow silty and silty fractions, which are due to as a selective loss of syringil aromatic structures, and demethylation of metaxylene groups.

Adsorption of lignin phenols on the mineral surface is facilitated by the high specific surface area of the mineral phase and its positive charge. Biopolymer molecules are encrusted with clay minerals and become inaccessible to microorganisms. This is probably the reason for the high correlation between lignin content (VSC) and specific soil surface values. High values of specific surface area are caused by the presence of mixedlayer minerals in the studied soils. Layered silicates are represented by illite (polytype 2M1), kaolinite (low-temperature polytype 1TC), and vermiculite (polytype 2M) and illitemontmorillonite. It can be assumed that oxidized lignin monomers are fixed by clay minerals. The "ideal" matrix for adsorption of lignin phenols and enzymes is amorphous Fe and Al hydroxides. They are widely distributed in the soil in the free form or in the form of Fe-Mn nodules.

Table 1. Lignin parameters of soil gran-size fractions

\begin{tabular}{lccccc}
\hline $\begin{array}{l}\text { Soil }(\mathrm{mm}), \text { fractions, } \\
(\mu \mathrm{m})\end{array}$ & $\begin{array}{c}\text { Lignin } \\
(\mathrm{VSC}), \\
\mathrm{mg} \mathrm{g}^{-1} \text { Corg }\end{array}$ & $\begin{array}{c}\text { Syringic phenols/ } \\
\text { vanillic phenols } \\
(\mathrm{S} / \mathrm{V})\end{array}$ & $\begin{array}{c}\text { Vanillic } \\
\text { acids/ } \\
\text { vanillin } \\
(\text { ac/al })_{\mathrm{v}}\end{array}$ & $\begin{array}{c}\text { Syringic acids/ } \\
\text { syringic } \\
\text { aldehydes } \\
(\text { ac/al })_{\mathrm{s}}\end{array}$ & $\begin{array}{c}\text { Amino } \\
\text { sugar, }_{\mathrm{mg} \mathrm{g}^{-1} \mathrm{~N}}\end{array}$ \\
\hline Soil, $<2 \mathrm{~mm}$ & 11.6 & 0.80 & 0.27 & 0.40 & 70.9 \\
\hline Clay, $0-2 \mu \mathrm{m}$ & 6.7 & 1.09 & 0.33 & 0.45 & 38.3 \\
\hline Silt, $2-20 \mu \mathrm{m}$ & 18.9 & 0.75 & 0.29 & 0.41 & 48.9 \\
\hline
\end{tabular}

Acknowledgements. This work has supported by RSF (grant 17-14-01120).

References

1. Kovalev I.V., Kovaleva N.O. // In: 19th International Conference of Humus Substances and their Contribution to the Climate Change Mitigation, 16-21 September, 2018, Albena Resort, Bulgaria, pp. 119-122. 